\title{
Distribution of Carbon Dioxide Released in a Field Crop
}

\author{
Shinichi TAKam I* and C.H.M. VAN BAVEL \\ ( $\left.\begin{array}{c}\text { Department of Soil and Crop Sciences, Texas Agricultural Experiment } \\ \text { Station, Texas A\&M University, College Station, Texas } 77843 .\end{array}\right)$
}

\begin{abstract}
A model to deal with the two-dimensional diffusion of carbon dioxide, released at ground level, within and above a crop canopy was developed and tested experimentally. The $\mathrm{CO}_{2}$ was released from a uniform area source at ground level and at a constant rate. The crop canopy was assumed to be horizontally uniform and infinite. The steady-state $\mathrm{CO}_{2}$ distribution was obtained as a solution of the two-dimensional diffusion equation by the forward finite-difference approximation, using a digital computer. Theoretical wind and eddy diffusivity profiles for above and within the canopy were incorporated. Crop assimilation was neglected.

The crop canopy was characterized by its aerodynamic parameters: crop height, zero-plane displacement, roughness length and exponential coefficient of the within-canopy wind profile. The model calculated the $\mathrm{CO}_{2}$ profile as a function of down-wind distance, wind speed in the crop surface boundary layer, $\mathrm{CO}_{2}$ release rate, and $\mathrm{CO}_{2}$ concentration at the upwind edge of the source. The influence of crop canopy structure on the $\mathrm{CO}_{2}$ profile was found by changing the aerodynamic canopy parameters.

A series of $\mathrm{CO}_{2}$ diffusion field experiments was conducted in a cotton canopy. All input parameters in the model, except the exponential coefficient of the within-canopy wind profile, were measured. $\mathrm{The}^{\mathrm{CO}} \mathrm{O}_{2}$ profiles at a fixed down-wind distance were determined and compared with those predicted by the model.

The model overestimated the $\mathrm{CO}_{2}$ concentration in the lower layer of the canopy by about $50 \%$ when the leaf area index was 2.33 and the canopy was open. The difference between predicted and measured values was 20 to $30 \%$ when the leaf area index was 2.74 and the canopy was denser due to branching in the upper layers. It was concluded that the model can give a useful approximation of the distribution of $\mathrm{CO}_{2}$ in a dense and uniform canopy, when wind fluctuations are small, and under thermally neutral conditions.
\end{abstract}

\section{Introduction}

Carbon dioxide assimilation is one of the basic processes by which a plant accumulates dry matter. In the process, a plant converts water and carbon dioxide into carbohydrates with the aid of solar energy and minerals. The process rate depends on the ambient $\mathrm{CO}_{2}$ concentration as well as soil water conditions, the amount of photosynthetically active radiation, and minerals available in the soil. Laboratory experiments with closed systems have shown that the $\mathrm{CO}_{2}$ assimilation rate increases as $\mathrm{CO}_{2}$ concentration increases, up to

Read at the Kanto Branch Meeting, Tokyo, May 8th, 1975.

Received on March 8th, 1975.

* 現在：東京大学農学部 more than 1000 ppm (e.g., Gaastra, 1956). This fact has stimulated the interest in $\mathrm{CO}_{2}$ enrichment in field crop production (Van Bavel, 1972).

In the crop physiology literature, however, little attention has been paid to the effect of $\mathrm{CO}_{2}$ concentration on crop assimilation rate, as compared with the effect of light, water and minerals. This is because the $\mathrm{CO}_{2}$ concentration has often been regarded as not limiting the process, since its variation from the average atmospheric concentration (about $320 \mathrm{ppm}$ ) is comparatively small under normal field conditions. The variations of soil water, minerals and light are much greater, and affect field crop productivity significantly.

However, recent measurements (e.g., Uchijima, Udagawa, Horie, and Kobayashi, 1967; Brown and 
Rosenberg, 1970) have suggested that sometimes the $\mathrm{CO}_{2}$ concentration may be depressed so as to affect crop assimilation in the upper canopy layers, under high irradiance and low wind speeds in a well watered field. Under such conditions, $\mathrm{CO}_{2}$ concentrations of less than $250 \mathrm{ppm}$ have been observed near the top of the crop canopy, and the question has been raised whether the crop assimilation can be enhanced by increasing the $\mathrm{CO}_{2}$ concentration in the crop artificially.

Kretchman and Howlett (1970) attempted to determine $\mathrm{CO}_{2}$ effects on plants in the field, but they did not obtain enough supporting micrometeorological data to explain their results. Harper (1971) and Harper, Baker, Box and Hesketh (1973) did intensive $\mathrm{CO}_{2}$ release experiments, both in cotton and coastal bermudagrass. They not only measured $\mathrm{CO}_{2}$ profiles and pertinent meteorological parameters, but also estimated crop $\mathrm{CO}_{2}$ assimilation rate as influenced by $\mathrm{CO}_{2}$ release, using data from a leaf chamber in situ, coupled with measured environmental conditions. Despite their valuable data, they were unable to predict the effect of $\mathrm{CO}_{2}$ release on crop assimilation rate for other canopies and environmental conditions, as they failed to predict the $\mathrm{CO}_{2}$ concentrations under enrichment.

At the same time, turbulent transfer theory has been introduced into the study of the $\mathrm{CO}_{2}$ environment within the crop canopy, as an element of the theoretical approach to the study of field crop production.

Budyko, Gandin and Efimova (1966), Uchijima and Inoue (1970), Duncan and Barfield (1970) Allen, Jensen and Lemon (1971), and Lemon, Stewart and Shawcroft (1971) used a one-dimensional diffusion equation to describe the $\mathrm{CO}_{2}$ concentration within the canopy, as affected by the crop assimilation rate. Varying the soil $\mathrm{CO}_{2}$ flux, thereby simulating varying degrees of enrichment, they solved the equation numerically to give the $\mathrm{CO}_{2}$ profile and $\mathrm{CO}_{2}$ flux.

However, the one-dimensional model is not realistic for the study of artificial $\mathrm{CO}_{2}$ release, since it assumes an infinite, uniform $\mathrm{CO}_{2}$ area source at the ground, level. In reality, the source area is finite in size, and advection plays an important role in the distribution of the released $\mathrm{CO}_{2}^{\circ}$

A one-dimensional model is also inadequate for describing the $\mathrm{CO}_{2}$ environment under natural conditions, because there different boundary conditions, associated with different crop canopies, may prevent the development of a unique $\mathrm{CO}_{2}$ boundary layer along the direction of wind flow.

Inoue (1974) and Allen $(1973,1974)$ utilized a twodimensional diffusion equation. Inoue (1974) conducted numerical experiments to predict the change in the $\mathrm{CO}_{2}$ profile with downwind distance over a finite vegetation, as affected by the crop assimilation rate and soil $\mathrm{CO}_{2}$ flux. He did not calculate the distribution of $\mathrm{CO}_{2}$ within the canopy, but assumed that the concentration there was constant. Direct experimental test of his model was not provided. With essentially the same model, Allen $(1973,1974)$ simulated $\mathrm{CO}_{2}$ release from a line source in conjunction with field experiments in corn crop by Allen, Desjardins and Lemon (1974). He also examined area source diffusion numerically, approximating it with closely adjacent line sources.

The investigations made so far are insufficient in evaluating $\mathrm{CO}_{2}$ enrichment in field crops for the following reasons:

1. The two-dimensional $\mathrm{CO}_{2}$ diffusion from an area source at a ground level in a crop has not been solved with the proper boundary conditions and realistic eddy diffusivity profiles.

2. Solutions of the two-dimensional diffusion equation for an area source in a crop have not been directly tested by experiment.

The first objective of this research was to develop a model to predict $\mathrm{CO}_{2}$ distribution from an area source, on the basis of the two-dimensional diffusion equation with realistic boundary conditions and eddy diffusivity profiles.

The second objective was to test the model by experimentation in the field.

\section{Methods and Materials}

\subsection{Theoretical}

\section{Model Design}

Figure 1 illustrates an idealized field for which the model was developed. The $X$ axis is taken in the downwind direction, the $Y$ axis in the crosswind direction and the $Z$ axis in the vertical direction. The space is vertically divided into three layers: (i) the soil layer, (ii) the crop canopy layer, and (iii) the surface boundary layer developed above the canopy. The mean crop canopy height, measured from the ground surface, 


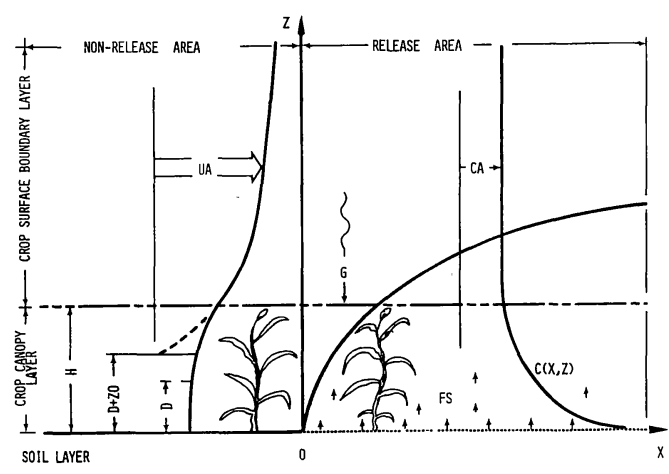

Fig. 1. An idealized field for which the model is developed.

defines the interface between (ii) and (iii).

The soil surface is divided into two regions in the $X$ direction: one is the $\mathrm{CO}_{2}$ release area $(X>0)$, and the other the non-release area $(X \leq 0)$. The $\mathrm{CO}_{2}$ flux from the soil surface $\left(F S, \mathrm{gm}^{-2} \mathrm{~s}^{-1}\right)$ is assumed to be equal to the release rate, as the natural soil $\mathrm{CO}_{2}$ flux is two orders of magnitude smaller than the release rates used in this study.

The crop canopy is assumed to be infinite and homogeneous in both $X$ and $Y$ directions. It is regarded as an assembly of leaves layered in the $Z$ direction. The mean geometrical height of the canopy $(H, \mathrm{~m})$ and the log-law and exponential wind profile parameters (defined later) characterize the crop canopy. The carbon dioxide assimilation by the crop is neglected, as a first approximation. This assumption is permissible in the $\mathrm{CO}_{2}$ balance under $\mathrm{CO}_{2}$ enrichment, since the sink intensity is much smaller in this case than in the case of natural conditions.

The boundary air layer developed above the crop surface is specified by the steady state wind speed in the $X$ direction $\left(U A, \mathrm{~ms}^{-1}\right.$ ), which obeys the log-law wind profile, and by the $\mathrm{CO}_{2}$ concentration at the upwind edge of the release area $\left(C A, \mathrm{gm}^{-3}\right)$.

With the above assumptions, the $\mathrm{CO}_{2}$ concentration at any given point of the space can be obtained as a particular solution of the steady-state two-dimensional diffusion equation:

$$
U \frac{\partial C}{\partial X}=\frac{\partial}{\partial Z}\left(K \frac{\partial C}{\partial Z}\right)
$$

in which

$U=$ wind speed at height $Z, \mathrm{~ms}^{-1}$
$K=$ eddy diffusivity at height $Z, \mathrm{~m}^{2} \mathrm{~s}^{-1}$

$C=\mathrm{CO}_{2}$ concentration at $(X, Z), \mathrm{gm}^{-3}$

Under neutral stability conditions the following profiles (log-law profile) of wind and of eddy diffusivity hold for the above-canopy space (Sutton, 1953):

$$
\begin{aligned}
& U=\left(U_{*} / k\right) \ln ((Z-D) / Z 0) \\
& K=k U_{*} \ln (Z-D)
\end{aligned}
$$

where

$$
\begin{aligned}
U_{*} & =\frac{U A}{\ln ((Z-D) / Z 0)}, \text { friction velocity, } \mathrm{ms}^{-1} \\
k & =\text { Von Karman constant }(\simeq 0.4) \\
D & =\text { zero-plane displacement, } \mathrm{m} \\
Z 0 & =\text { roughness length, } \mathrm{m} \\
U A & =\text { the wind speed at the height of } Z A \mathrm{~m}, \mathrm{~ms}^{-1}
\end{aligned}
$$

For the space within the canopy the following profiles are assumed to hold (Inoue, 1963):

$$
\begin{aligned}
& U=U H * \exp (-A(1-Z / H)) \\
& K=K H * \exp (-A(1-Z / H))
\end{aligned}
$$

where

$$
\begin{aligned}
& U H=\text { wind speed at crop height }(H), \mathrm{ms}^{-1} \\
& K H=\text { eddy diffusivity at crop height, } \mathrm{m}^{2} \mathrm{~s}^{-1}
\end{aligned}
$$

The parameter $A$ is a complex quantity relating to the leaf area density, drag coefficient of leaves and eddy size within the canopy (Inoue, 1963).

The boundary conditions assumed are:

$$
\begin{aligned}
C=C A & ; X=0, & Z \geqq 0 \\
C=C A & ; Z=Z H, & X \geqq 0 \\
-K \frac{\partial C}{\partial Z}=F S & ; 0<X, & Z=0
\end{aligned}
$$

where $\mathrm{ZH}$ is the height of $\mathrm{CO}_{2}$ boundary layer, defined as the height at which $C$ converges to $C A$, as explained further on.

Numerical Method

To solve equation (1) with equations (2) through (5) under the restrictions of equations (6) through (8), these relations are transformed into non-dimensional coordinates defined as:

$$
\begin{aligned}
V & =\left(K H /\left(U H * H^{2}\right)\right) * X \\
W & =Z / H
\end{aligned}
$$

With this transformation, the diffusion equation and profiles, for both spaces, can be expressed as:

$$
\begin{aligned}
& \partial C / \partial V=G 1(\partial C / \partial W)+G 2\left(\partial^{2} C / \partial W^{2}\right) \\
& U=U H * F U, \quad K=K H * F K
\end{aligned}
$$


In the above relations, $F U$ and $F K$ are the dimensionless wind and eddy diffusivity profiles, respectively, and $G 1$ and $G 2$ are defined as:

$$
\begin{aligned}
& G 1=(d(F K) / d W) / F U \\
& G 2=F K / F U
\end{aligned}
$$

In the case that the profiles are given by equations (2) through (5), these functions become:

within the canopy: $F U=F K=\exp (-A(1-W))$

$$
G 1=A, G 2=1
$$

above the canopy: $F U=\ln ((W-W D) / W Z 0) /$

$$
\begin{aligned}
& \ln ((1-W D) / W Z 0) \\
F K= & (W-W D) /(1-W D) \\
G 1= & 1 / F U, G 2=F K / F U
\end{aligned}
$$

where $W D=D / H$, dimensionless zero-plane displacement

$W Z 0=Z 0 / H$, dimensionless roughness length

The boundary conditions given by equations (6), (7), and (8) are also transformed:

$$
\begin{aligned}
& C(0, W)=C A ; \quad V=0, W \geq 0 \\
& C=C A \quad ; \quad W=W H \\
& F K *(\partial C / \partial W)=-F 1 ; 0<V, \quad W=0
\end{aligned}
$$

where $F 1=F S * H / K H$

By means of the forward difference scheme, equations (9) and (16) are approximated as:

$$
\begin{gathered}
C(I+1, J)=C(I, J)+R 1 * G 1 *(C(I, J+1)-C(I, J)) \\
+R 2 * G 2 *(C(I, J+1)+2 *(C(I, J)+C(I, J-1)) \\
R 1 \equiv \Delta V / \Delta W \\
R 2 \equiv \Delta V /(\Delta W)^{2} \\
C(I, 1)=C(I, 2)+(F 1 / F K) \Delta W
\end{gathered}
$$

where $\Delta V$ is the mesh spacing in the $V$-direction and $\Delta W$ the mesh spacing in the $W$-direction.

The first step of computation is to solve $C(2,2)$ by equation (17) with the specified values of $C(1,1), C(1,2)$ and $C(1,3)$ given as a boundary condition (equation 15 ). This procedure is repeated in the $W$-direction (height) for all mesh points at $I=2$, until another boundary condition (equation 15) is satisfied. Then the value $C(2,2)$ is used to determine $C(2,1)$ according to equation (18) (flux boundary condition). In these calculations the $\mathrm{CO}_{2}$ concentration is expressed in $\mathrm{gm}^{-3}$, as the units in equation (1) through (8) indicate. Then, it is converted to ppm in the end of the program, on the basis that $1.0 \mathrm{gm}^{-3}$ of $\mathrm{CO}_{2}$ equals $556 \mathrm{ppm}$. The above procedures are repeated in the $V$-direction (downwind) step by step.

It should be noticed that the $\mathrm{CO}_{2}$ boundary layer height $\mathrm{ZH}$ is, at first, neither fixed nor known, but is to be determined by the above procedures. This is one of the essential differences between our method and those used by Allen (1974) and Inoue (1974), who assumed a fixed upper boundary. This may affect the development of calculated $\mathrm{CO}_{2}$ boundary layer.

\section{Input Data for Numerical Experiments}

Aerodynamically, a crop canopy may be broadly classified as a (1) sparse and smooth, (2) sparse and rough, (3) dense and rough, and (4) dense and smooth

\begin{tabular}{|c|c|c|c|c|c|}
\hline Canopy** & $\begin{array}{c}H \\
(\mathrm{~m})\end{array}$ & $\begin{array}{c}D \\
(\mathrm{~m})\end{array}$ & $\begin{array}{l}Z 0 \\
(\mathrm{~m})\end{array}$ & $A$ & $L A I$ \\
\hline 1 & 1.0 & 0.5 & 0.05 & 3.00 & -- \\
\hline 2 & $"$ & " & 0.15 & $"$ & -- \\
\hline 3 & $"$ & 0.8 & " & $"$ & - \\
\hline 4 & $"$ & " & 0.05 & $"$ & 8.0 \\
\hline 5 & $"$ & 0.5 & 0.15 & 2.00 & 2.5 \\
\hline $\begin{aligned} & * \quad H=\text { crop } \\
& D=\text { zerc } \\
& Z 0=\text { roug } \\
& A=\text { coef } \\
& \text { win } \\
& L A I= \text { leaf } \\
& * * \text { Canopy } 1= \\
& 2 \\
& 3= \\
& 4= \\
& 5=\end{aligned}$ & $\begin{array}{l}\text { cano } \\
\text {-plane } \\
\text { hness } \\
\text { ficien } \\
\text { profi } \\
\text { area ir } \\
\text { a spa } \\
\text { a spa } \\
\text { a den } \\
\text { a den } \\
2 \text { wit }\end{array}$ & $\begin{array}{l}\text { heigh } \\
\text { isplac } \\
\text { ngth } \\
n \text { the } \\
\text { ex } \\
\text { and } \\
\text { and } \\
\text { and } s\end{array}$ & $\begin{array}{l}\text { uation } \\
\text { ooth c } \\
\text { ugh car } \\
\text { igh can } \\
\text { ooth ca }\end{array}$ & $\begin{array}{l}\text { f with } \\
\text { nopy } \\
\text { opy } \\
\text { py } \\
\text { nopy }\end{array}$ & n-canopy \\
\hline
\end{tabular}
surface, according to the values of $D$ and $Z 0$ for a given value of $H$ (Takeda, 1966). This is because $Z 0$ characterizes the roughness of the surface and larger values of $D$ are associated with denser canopies of equal height. Table 1 gives some possible combinations of $D$ and $Z 0$, corresponding to the above classifications (canopy 1 through 4). The values of $D$ and $Z 0$ are normalized by crop height $(H)$, so as to eliminate its effect. The value of $A$ is kept constant at 3.00 , the maximum possible value for the range of $A$ (Inoue, 1963). To see the effect of $A$, however, an additional canopy (canopy 5) is

Table 1. Aerodynamic properties and leaf area index ( $L A I)$ of crop canopies used in the simulation* 
added by decreasing $A$ to its possible minimum, 2.00, for the canopy 2. This value of $A$ actually corresponds better to the nature of a sparse and rough canopy, than the value used in canopy 2 , as a smaller value of $A$ implies slow decline of wind speed toward the bottom of the canopy.

In plant production, the $L A I$ is the most important and commonly used index of canopy size. It is also a more intrinsic quantity than $D$ and $Z 0$. In order to calculate its effect on the $\mathrm{CO}_{2}$ distribution two values for $L A I$ (8.0 and 2.5) were assumed (canopies 4 and 5, respectively) and the corresponding aerodynamic parameters were estimated from a semi-empirical relation (Takami, 1974).

The simulation was carried out with the five different canopy types (Table 1), for a wind speed of $2 \mathrm{~ms}^{-1}$ at $2 \mathrm{~m}$ height, and with a release rate of $0.01 \mathrm{gm}^{-2} \mathrm{~s}^{-1}$. For the canopy 1 only, two additional calculations with wind speeds of $1 \mathrm{~m} \mathrm{~s}^{-1}$ and $3 \mathrm{~m} \mathrm{~s}^{-1}$ were made, to examine the effect of wind speed, and another with a release rate of $0.02 \mathrm{gm}^{-2} \mathrm{~s}^{-1}$, to examine the effect of the release rate.

\subsection{Experimental}

\section{Site and Crop}

The experimental site (Fig. 2), block 7-D on the Texas A\&M Farm near College Station, Texas, was a $82 \mathrm{~m}$ by $120 \mathrm{~m}$ level field. A $24 \mathrm{~m}$ by $24 \mathrm{~m}$ subplot, where the canopy was fairly uniform, was chosen as the release area. The micrometeorological instruments, were also set up in this area. The prevailing wind was between east and south. The wind fetch was about $30 \mathrm{~m}$ for a southerly wind and about $60 \mathrm{~m}$ for an easterly wind. In the southerly direction, there were seven rain shelters, a mobile van and two small portable buildings fairly close by. The nearest obstacle in the easterly direction was a pecan orchard about $400 \mathrm{~m}$ upwind. The northern side of the site was cultivated area, stretching for more than $1 \mathrm{~km}$ with scattered cotton and corn plots. There was a narrow road on the west side, across which was a large pasture.

The crop, cotton (Gossypium hirsutum L., var. Stoneville 213), was sown on April 26-29, 1974. The rows were $1 \mathrm{~m}$ apart and oriented approximately eastwest. Plants emerged from May 1 through May 4. The site was fertilized on May 20 and cultivated several times

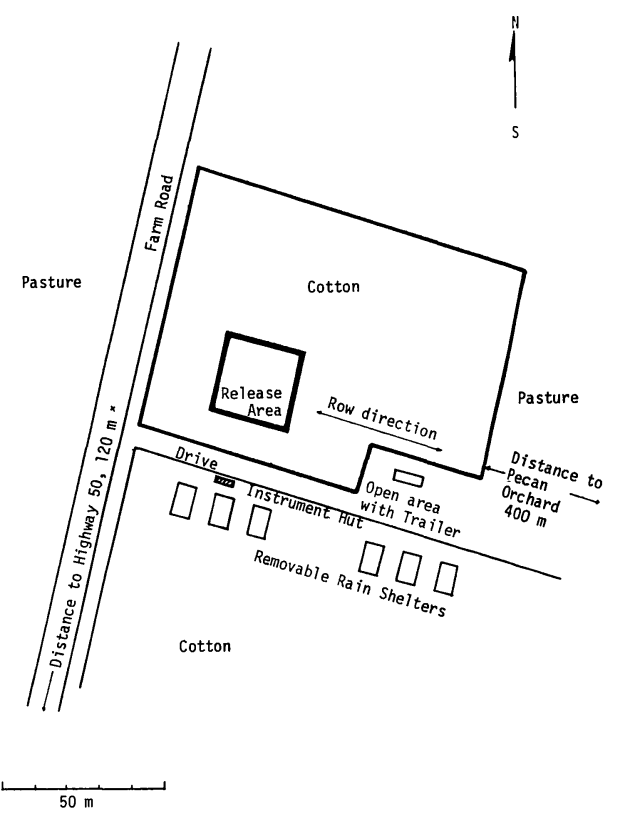

Fig. 2. Map of experimental site, A\&M Farm, near College Station, Texas.

to control weeds, prior to the experimental measurements. By June 24, the crop reached approximately $0.6 \mathrm{~m}$ height, a $L A I$ of about 1.5 , and had initiated flowering.

\section{Instrumentation}

The parameters needed as inputs into the model are: $\mathrm{CO}_{2}$ concentration in the non-release area $\left(C A, \mathrm{gm}^{-3}\right)$, wind speed above the crop at height $Z A \mathrm{~m}\left(U A, \mathrm{~m} \mathrm{~s}^{-1}\right)$, release rate $\left(F S, \mathrm{~g} \mathrm{~m}^{-2} \mathrm{~s}^{-1}\right)$, the canopy height $(H, \mathrm{~m})$, above-canopy wind profile parameters $(D, \mathrm{~m}$ and $Z 0, \mathrm{~m})$, and within-canopy wind profile parameter $(A)$. All paremeters, except $A$, were measured or calculated from field measurements. The parameter $A$ was taken as 2.80 , as obtained for a corn canopy by Inoue (1963). This value is fairly universal and $A$ has little effect on $\mathrm{CO}_{2}$ distribution.

Fig. 3 illustrates the layout of the instrumentation in the subplot area. Wind speed at 1 to $2 \mathrm{~m}$ above the ground was measured by a Rimco cup anemometer (contact type R/AMC). With an additional four anemometers at different heights, we measured wind profiles to obtain $D$ and $Z 0$.

We measured air temperatures at $1 \mathrm{~m}$ and $2 \mathrm{~m}$ height, with ventilated $\mathrm{Cu}-\mathrm{Co}$ thermocouples mounted in 


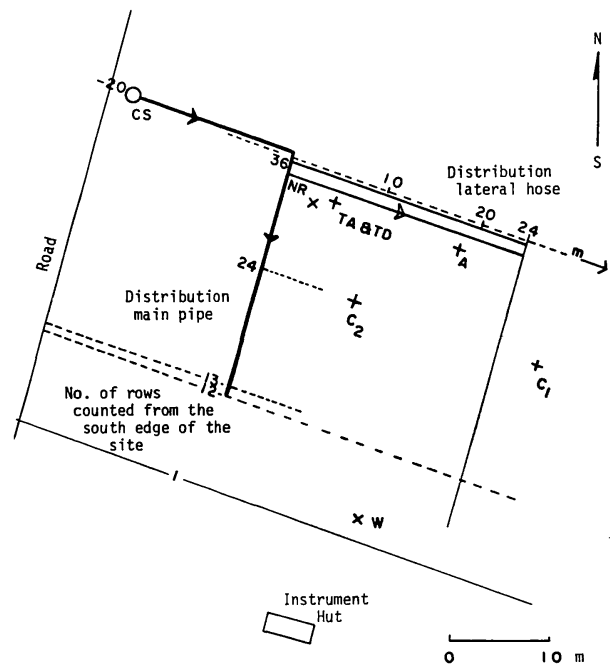

Fig. 3. Subplot for $\mathrm{CO}_{2}$ release and micrometeorological instrumentation.

$A=$ Anemometer

$C_{1}=$ Upwind $\mathrm{CO}_{2}$ sampling mast

$C_{2}=$ Downwind $\mathrm{CO}_{2}$ sampling mast

$C S=\mathrm{CO}_{2}$ cylinders

$T A \& T D=$ Temperature \& Dewpoint mast

$W=$ Wind vane

$N R=$ Net radiometer

$\rightarrow=$ Flow direction of $\mathrm{CO}_{2}$

double-shielded nozzles made of rigid PVC pipe. A windvane (Windscope, No. 3105), located near the southern edge of the site at $1.5 \mathrm{~m}$ height, monitored wind direction. Shortwave irradiance was measured by a Kipp solarimeter (Model CM2) on the roof of the instrument hut. Net radiation was occasionally measured by a Fritschen type net radiometer.

The output signals from radiometers and thermocouples were connected directly to a Datex digital recorder and the values were recorded by a Teletype printer. The anemometer counts were accumulated on Durant counters and were recorded through the Datex and Teletype at five minute scanning intervals. Windvane outputs were recorded separately on a strip chart recorder. All instruments were calibrated before being exposed in the field.

The carbon dioxide gas was discharged from 25 lateral distribution hoses laid in each furrow. Each lateral was a $24 \mathrm{~m}$ long, flexible twin-wall drip irrigation hose (Chapin Watermatics). The inner tube was $12.7 \mathrm{~mm}$ in diameter with $0.6 \mathrm{~mm}$ holes spaced every $1.83 \mathrm{~m}$. The

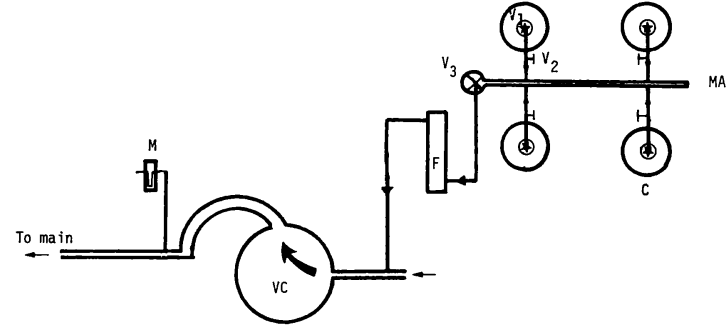

Fig. 4. Schematic diagram of $\mathrm{CO}_{2}$ source and monitor system.

$$
\begin{array}{rlrl}
C & =\mathrm{CO}_{2} \text { cylinder } & F & =\text { Flow meter } \\
V_{1} & =\text { Main valve } & V C & =\text { Vacuum cleaner } \\
V_{2} & =\text { Regulator } & M & =\text { Mercury manometer } \\
V_{3} & =\text { Final adjustment valve } \\
M A & =\text { Manifold } &
\end{array}
$$

Arrows indicate the flow direction.

outer tube was slightly larger, containing $0.6 \mathrm{~mm}$ holes, spaced $0.46 \mathrm{~m}$ apart. Each lateral hose was connected to a $24 \mathrm{~m}$ long, $50 \mathrm{~mm}$ diameter PVC main pipe, with T joints spaced $1 \mathrm{~m}$ apart. The PVC pipe was laid across the rows. The $\mathrm{CO}_{2}$ was delivered to this main pipe from standard commercial $\mathrm{CO}_{2}$ cylinders.

The $\mathrm{CO}_{2}$ from the cylinders was mixed with air and delivered to the main pipe by a canister vacuum cleaner which inflated the flexible lateral hoses (Fig. 4). A Utube mercury manometer connected to the inlet of the main pipe monitored a predetermined pressure to ensure the necessary air flow rate. The flow rate of $\mathrm{CO}_{2}$ was meastured by a flowmeter (Brooks Fullview Rotameter, Model 110-10H 3B1A).

The ambient air was sampled for $\mathrm{CO}_{2}$ analysis at two locations (Fig. 3): $4 \mathrm{~m}$ east of the eastern edge of the release area $\left(C_{1}\right)$, and $10 \mathrm{~m}$ east from the distribution main pipe $\left(C_{2}\right)$. The upwind mast had two sampling nozzles at $0.35 \mathrm{~m}$ and $2.55 \mathrm{~m}$ above the ground. The downwind mast had five nozzles at $0.15,0.35,0.75$, 1.55 and $2.55 \mathrm{~m}$.

Sample air was pumped through a low density polyethylene line by an aquarium pump in the instrument hut (Fig. 5). It was delivered into a "chemton" gas sampling bag $(0.30 \times 0.30 \mathrm{~m}, 0.254 \mathrm{~mm}$ Teflon FEP $)$. The error introduced by $\mathrm{CO}_{2}$ evolution in the $60 \mathrm{~m}$ long polyethylene tubing was less than $2 \mathrm{ppm}$, for the flow rate used. The air stored in the bag was pumped to a gas analyzer (Beckman IRGA, model 315A, differential infrared) for analysis immediately after filling. 



Fig. 5. Schematic diagram of $\mathrm{CO}_{2}$ sampling and analyzing system.

$$
L=\text { Field sampling line } A=\text { Analyser inlet }
$$$$
P=\text { Pump } \quad B=\text { Storing bag }
$$$$
F=\text { Flow indicator } \quad V_{1}, V_{2}=3 \text {-way valves }
$$

Arrow indicates the direction of flow.

\section{Experimental Procedure}

Three series of experiments were conducted at ten to fourteen day intervals as the crop canopy developed. $\mathrm{CO}_{2}$ release experiments, wind profile measurements and canopy structure measurements were made separately during each experimental series.

The $\mathrm{CO}_{2}$ release experiments were conducted when the wind speed and direction stayed almost steady over thirty to sixty minutes. The $\mathrm{CO}_{2}$ was released for about twenty minutes. During this period air was sampled for 10 minutes. Wind speed at one level above the canopy, temperature at two heights and wind direction at $1.5 \mathrm{~m}$ height were recorded simultaneously. Most release experiments were carried out before sunrise or after sunset, as the surface air layer is usually neutral and steady at this time of the day.

Wind profile measurements were made over a ten minute period, when the wind speed was high. Wind profile parameters $\left(U_{*}, D\right.$ and $Z 0$ ) were determined for each profile by the least squares method.

The plant height was measured on 20 to 30 plants. Leaves of another 6 to 10 plants were clipped at $0.2 \mathrm{~m}$ height intervals (except $0.15 \mathrm{~m}$ in the lowest stratum). The total leaf area of each layer was measured for every plant by an automatic area meter (Model AAM5, Hayashi Denko)

\section{Data Analysis}

The meteorological data (wind, temperature, dew point and irradiance) were averaged over a sampling period of 10 minutes. This sampling period started 5 minutes prior to the air sampling. The time difference is equal to the time taken for air to flow through the field sampling line to the sampling bags.

\section{Results and Discussion}

\subsection{Crop Canopy Geometry and Aerodynamics}

Fig. 6 illustrates the profiles of the leaf area density ( $L A D, L A I$ defined as per unit thickness of layer) for each experimental period. The profiles were calculated from three-degree polynomials fitted to the original data. Data were obtained during three separate stages of development, I, II, and III (see Table 2).

The crop canopy became denser and more uniform from I to II, by $15 \%$ in terms of $L A I$. Prior to stage III the canopy had lost some lower leaves and the $L A I$ had decreased. A dense and uniform canopy was not obtained, because of inadequate rainfall.

Ten-minute average wind speeds at five levels measured on July 13, July 30 and August 10 are tabulated in Table 2. The thirty-minute average for the July 13 and August 10 measurements and the fifty-minute average for the July 30 measurement are also given, as is the wind direction during each period of measurement.

Table 2 also presents the corresponding values of the log-law profile parameters, i.e., the zero-plane displacement $(D)$, the roughness length $(Z 0)$ and the friction velocity $\left(U_{*}\right)$. The wind speed at $3.35 \mathrm{~m}$ height on July 13 and August 10 was omitted in the calculation, as it deviated too far from the log-law.



Fig. 6. Profiles of leaf area density $(L A D)$ for each period of experiment, calculated from threedegree polynomial. $L A I: \quad \mathrm{I}=2.33, \quad \mathrm{II}=2.74$, $\mathrm{III}=2.25$. 
Table 2. Wind speed measured at five levels above the canopy and the log-law profile parameters calculated for each profile.

\begin{tabular}{|c|c|c|c|c|c|c|c|c|c|c|c|}
\hline \multirow{3}{*}{ Exp. } & \multirow{3}{*}{ Day } & \multirow{3}{*}{$\begin{array}{l}\text { Time } \\
\text { CDT }\end{array}$} & \multicolumn{5}{|c|}{ Height $(m)$} & \multirow{3}{*}{$\begin{array}{c}\text { Wind } \\
\text { Direction }\end{array}$} & \multicolumn{3}{|c|}{ Log-law profile parameters } \\
\hline & & & 0.95 & 1.15 & 1.55 & 2.35 & 3.35 & & $D$ & $Z 0$ & $U^{*}$ \\
\hline & & & \multicolumn{5}{|c|}{ wind speed $\left(\mathrm{m} \mathrm{s}^{-1}\right)$} & & (m) & (m) & \\
\hline \multirow[t]{4}{*}{ I } & July 13 & $1900-1910$ & 2.37 & 2.73 & 3.25 & 3.80 & 4.54 & ESE & 0.52 & 0.040 & 0.41 \\
\hline & & $1910-1920$ & 2.73 & 3.20 & 3.66 & 4.39 & 5.21 & $"$ & 0.42 & 0.060 & 0.52 \\
\hline & & $1920-1930$ & 2.38 & 2.79 & 3.26 & 3.69 & 4.38 & $"$ & 0.73 & 0.061 & 0.27 \\
\hline & & mean & 2.49 & 2.91 & 3.39 & 3.96 & 4.71 & $"$ & 0.59 & 0.024 & 0.38 \\
\hline \multirow[t]{6}{*}{ II } & July 30 & $1545-1555$ & 2.05 & 2.48 & 2.95 & 3.58 & 4.19 & NNW & - - & - & -- \\
\hline & & $1555-1605$ & 2.00 & 2.42 & 2.84 & 3.35 & 3.88 & $"$ & - - & - - & - \\
\hline & & $1605-1615$ & 1.82 & 2.18 & 2.56 & 3.05 & 3.51 & $"$ & - & -- & - \\
\hline & & $1615-1625$ & 1.98 & 2.45 & 2.90 & 3.55 & 4.11 & $\mathrm{~N}$ & 0.44 & 0.074 & 0.42 \\
\hline & & $1625-1635$ & 1.70 & 2.14 & 2.53 & 3.00 & 3.43 & $"$ & 0.62 & 0.038 & 0.33 \\
\hline & & mean & 1.91 & 2.33 & 2.76 & 3.31 & 3.82 & $"$ & 0.46 & 0.077 & 0.43 \\
\hline \multirow[t]{4}{*}{ III } & Aug. 10 & $1650-1700$ & 2.17 & 2.44 & 3.02 & 3.48 & 4.21 & $S$ & 0.51 & 0.046 & 0.39 \\
\hline & & $1700-1710$ & 2.63 & 2.98 & 3.73 & 4.27 & 5.15 & $"$ & 0.57 & 0.036 & 0.45 \\
\hline & & $1710-1720$ & 2.70 & 3.05 & 3.73 & 4.20 & 5.23 & $"$ & 0.62 & 0.018 & 0.38 \\
\hline & & mean & 2.50 & 2.82 & 3.49 & 3.98 & 4.86 & $"$ & 0.57 & 0.031 & 0.41 \\
\hline
\end{tabular}

The accurate determination of wind profile parameters is difficult, as the difference from one measurement to another on the same day in Table 2 indicates. In addition, it seemed unrealistic to characterize the aerodynamic nature of the crop canopy separately for each experimental period, since the fetch was different each time. Therefore, the values for the fiftyminute average profile of July 30 were used in the analysis of model calculations for all experiments. These values are $D=0.46 \mathrm{~m}, Z 0=0.077 \mathrm{~m}$ and agree well with values summarized by Stanhill and Fuchs (1968) and Monteith (1973).

\subsection{Meteorological Conditions and Input Data of Selected Experiments for the Model Test}

Table 3 gives the meteorological conditions and the release rate under which the $\mathrm{CO}_{2}$ release experiments were conducted. Six experiments, undertaken when wind was either easterly (along the rows) or southerly (across the rows), with small fluctuations under thermally near-neutral conditions, were chosen for the model test. The input data from these experiments are summarized in Table 4.

\subsection{Measured and Predicted Carbon Dioxide Profiles}

Fig. 7 shows the $\mathrm{CO}_{2}$ profiles both as measured and as predicted for three series of experiments, as identified in Table 4. The model overestimated the $\mathrm{CO}_{2}$ concentration inside the canopy. The discrepancy between predicted and measured values increased as the height decreased. The best agreement was obtained in the second series of experiments which was conducted with the densest and most closed canopy. Therefore, the discrepancies may be due to the fact that the canopy was not dense and homogeneous enough to satisfy the assumptions made in the model.

This inference was checked by additional calculations for the $\mathrm{CO}_{2}$ release experiments with both cotton and coastal bermudagrass by Harper (1971) and Harper et al. (1973).

The values of input parameters used in these calculations were as follows:

$\begin{array}{rll} & \text { Cotton } & \text { Coastal Bermudagrass } \\ U A\left(\mathrm{~ms}^{-1}\right) & 1.32 & 1.00 \\ Z A(\mathrm{~m}) & 1.50 & 1.50 \\ H(\mathrm{~m}) & 0.81 & 0.43 \\ D(\mathrm{~m}) & 0.67 & 0.27 \\ Z 0(\mathrm{~m}) & 0.039 & 0.056 \\ A & 2.80 & 2.18 \\ F S\left(\mathrm{gm}^{-2} \mathrm{~s}^{-1}\right) & 0.006 & 0.006 \\ C A\left(\mathrm{ppm}^{2}\right) & 349 & 349\end{array}$


S. TAKAMI and C.H.M. van BAVEL : Distribution of Carbon Dioxide Released in a Field Crop

Table 3. Pertinent data about the $\mathrm{CO}_{2}$ release experiment in 1974 in cotton at College Station, Texas.

\begin{tabular}{|c|c|c|c|c|c|c|c|c|c|c|}
\hline \multirow[b]{2}{*}{ Experiment } & \multirow[b]{2}{*}{ Day } & \multirow[b]{2}{*}{$\begin{array}{l}\text { Time } \\
\text { CDT* }\end{array}$} & \multirow{2}{*}{$\begin{array}{l}\text { Release } \\
\text { rate } \\
\mathrm{g} \mathrm{m}^{-2} \mathrm{~s}^{-1}\end{array}$} & \multicolumn{2}{|c|}{ Wind } & \multicolumn{3}{|c|}{ Temperature } & \multicolumn{2}{|c|}{ Radiation } \\
\hline & & & & $\begin{array}{l}\text { speed } \\
\mathrm{m} \mathrm{s}^{-1}\end{array}$ & $\begin{array}{c}\text { direction } \\
\text { deg** }\end{array}$ & $\mathrm{T}_{2}$ & $\begin{array}{l}\mathrm{T}_{1} \\
{ }^{\circ} \mathrm{C}\end{array}$ & $\begin{array}{l}\text { Dew } \\
\text { point }\end{array}$ & $\begin{array}{l}\text { Global } \\
\mathrm{W} \mathrm{m} \mathrm{m}^{-2}\end{array}$ & $\begin{array}{c}\text { Net } \\
\mathrm{W} \mathrm{m}^{-2}\end{array}$ \\
\hline I - 1 & July 11 & $0825-0835$ & 0.0075 & 2.75 & 323 & 25.8 & 26.1 & 22.1 & 326 & \\
\hline 2 & July 13 & $2055-2105$ & 0.0072 & $0.1^{* * *}$ & 11 & 27.7 & 26.0 & 19.6 & 0 & \\
\hline 3 & July 14 & $1540-1550$ & 0.0141 & $1.69^{+}$ & 120 & 35.5 & 35.5 & 21.2 & 820 & \\
\hline 4 & July 14 & $1955-2005$ & 0.0118 & $1.61^{+}$ & 311 & 23.4 & 23.4 & 20.2 & 14 & \\
\hline 5 & July 15 & $2100-2110$ & 0.0141 & $1.19^{+}$ & 289 & 26.6 & 26.5 & 20.2 & 0 & \\
\hline II - 1 & July 25 & $2020-2030$ & 0.0072 & 1.05 & 9 & 31.1 & 31.0 & 17.0 & 0 & \\
\hline 2 & July 26 & $2040-2050$ & $"$ & 0.67 & 251 & 29.7 & 29.3 & 21.5 & 0 & -24 \\
\hline 3 & July 28 & $1425-1435$ & $"$ & 0.98 & 300 & 35.6 & 35.8 & 18.8 & 715 & 566 \\
\hline 4 & July 28 & $2020-2030$ & $"$ & 1.20 & 338 & 29.8 & 29.4 & 16.4 & 0 & -52 \\
\hline 5 & July 29 & $0620-0630$ & $"$ & 1.05 & 289 & 21.8 & 21.6 & 18.8 & 0 & -39 \\
\hline 6 & July 30 & $0730-0740$ & $"$ & 1.27 & 278 & 23.6 & 23.8 & 19.7 & 41 & -11 \\
\hline III - 1 & Aug. 11 & $0740-0750$ & 0.0072 & $0.42^{++}$ & 337 & 24.3 & 24.3 & 22.1 & 47 & 25 \\
\hline 2 & Aug. 12 & $0650-0700$ & " & 1.21 & 315 & 22.8 & 22.5 & 20.7 & 7 & 13 \\
\hline 3 & Aug. 12 & $2340-2350$ & $"$ & 1.18 & 338 & 24.1 & 23.9 & 21.6 & 0 & -37 \\
\hline 4 & Aug. 13 & $0735-0745$ & $"$ & 0.58 & 310 & 23.6 & 23.8 & 21.8 & 51 & 48 \\
\hline 5 & Aug. 14 & $0730-0740$ & $"$ & 1.71 & 360 & 24.2 & 24.1 & 21.9 & 83 & 20 \\
\hline $\begin{array}{l}* \text { Central } \\
\text { ** measurec }\end{array}$ & ckwi & $\begin{array}{l}\text { time, (CST } \\
\text { om south }\end{array}$ & &,+++ & $\begin{array}{l}\text { timated } \\
\text { neasured } \\
\text { espectivel }\end{array}$ & 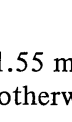 & se, at & $5 \mathrm{~m}$ & round, & \\
\hline
\end{tabular}

Table 4. Input data of the selected experiments for the model test.

\begin{tabular}{|c|c|c|c|c|c|c|c|c|}
\hline \multirow[b]{2}{*}{ Exp. } & \multirow[b]{2}{*}{$\begin{array}{l}\text { Fetch } \\
X(\mathrm{~m})\end{array}$} & \multirow[b]{2}{*}{$\begin{array}{l}C(1, J)^{1} \\
(\mathrm{ppm})\end{array}$} & \multicolumn{4}{|c|}{$\begin{array}{c}\text { Aerodynamic } \\
\text { canopy parameters }{ }^{2}\end{array}$} & \multirow{2}{*}{$\begin{array}{l}\text { Release } \\
\text { rate } \\
\left(\mathrm{g} \mathrm{m}^{-2} \mathrm{~s}^{-1}\right)\end{array}$} & \multirow{2}{*}{$\begin{array}{l}\text { Wind } \\
\text { speed } \\
\left(\mathrm{m} \mathrm{s}^{-1}\right)\end{array}$} \\
\hline & & & $\begin{array}{l}H \\
(\mathrm{~m})\end{array}$ & $\begin{array}{l}D \\
(\mathrm{~m})\end{array}$ & $\begin{array}{l}Z 0 \\
(\mathrm{~m})\end{array}$ & $A$ & & \\
\hline $\mathrm{I}-4$ & 14.0 & 349 & 0.73 & 0.46 & 0.077 & 2.80 & 0.0118 & $1.61^{3}$ \\
\hline I-5 & " & 358 & " & " & $"$ & $"$ & 0.0141 & $1.19^{3}$ \\
\hline II-2 & 14.0 & 341 & 0.73 & 0.46 & 0.077 & 2.80 & 0.0072 & 0.67 \\
\hline II-6 & " & 368 & $"$ & " & $"$ & $"$ & $"$ & 1.27 \\
\hline III-2 & 14.0 & 420 & 0.79 & 0.46 & 0.077 & 2.80 & 0.0072 & 1.21 \\
\hline III-4 & $"$ & 401 & $"$ & " & " & $"$ & $"$ & 0.58 \\
\hline
\end{tabular}

${ }^{1} \mathrm{C}(1, J)$ is the $\mathrm{CO}_{2}$ concentration measured at the leading edge of $\mathrm{CO}_{2}$ release area.

${ }^{2}$ Aerodynamic canopy parameters are $\quad H=$ canopy height

$$
\begin{aligned}
D & =\text { zero-plane displacement } \\
Z 0 & =\text { roughness length } \\
A & =\text { coefficient of exponential wind profile within canopy }
\end{aligned}
$$

${ }^{3}$ Measured at $1.55 \mathrm{~m}$ above the ground; otherwise, measured at $2.35 \mathrm{~m}$

The wind profile parameters for cotton are calculated from Harper's measurements. In the case of coastal bermudagrass the parameters had to be estimated except $H$, which was measured. The values of $D$ and $Z 0$ were found from Monteith's relations (1973), and $A$ was taken as 2.18 as obtained for a rice canopy (Inoue,
1963). The release rate was assumed to be the same as in the cotton experiment. The wind speed was chosen so that the calculated $\mathrm{CO}_{2}$ concentration at $1 \mathrm{~m}$ height became close to the measured one. The fetch for the profile was taken as $5.18 \mathrm{~m}$.

The result for the cotton experiment by Harper, in 


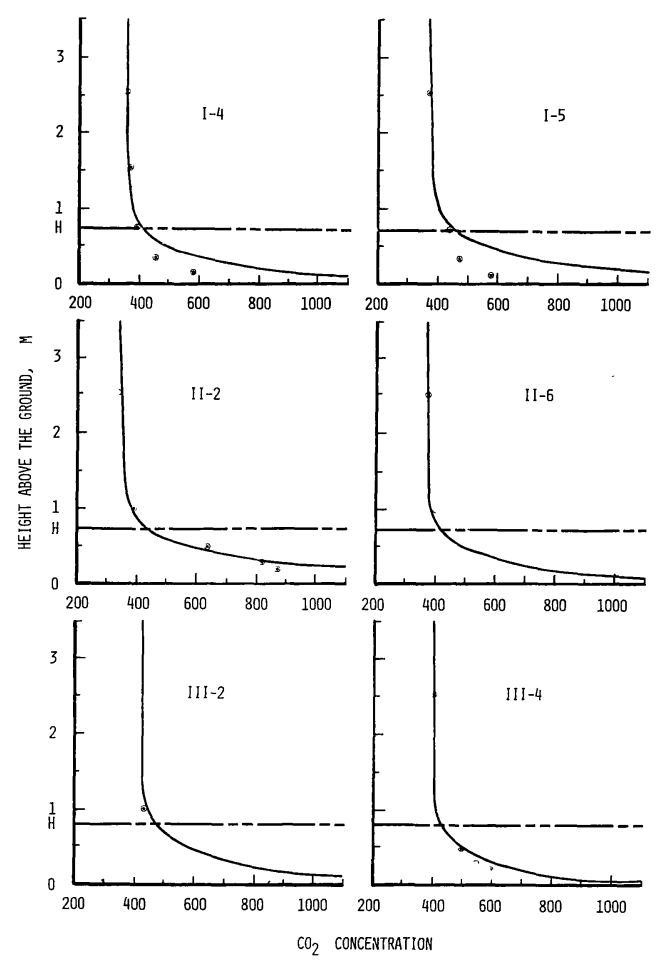

Fig. 7. Computed and measured ( $\odot)$ ) profiles in the selected experiments for the model test.

which the $L A I$ was 2.34 shows the same discrepancy within the canopy as in our experiments. On the other hand, the result for the bermudagrass with an $L A I$ of about 6 and a uniform stand, gave a good agreement inside the canopy (Fig. 8). Therefore, it appears that our model is reasonably valid for uniform stands.

\subsection{Extended Modeling of Carbon Dioxide Profiles}

In this section we use the model to examine its extended implications.

\section{Effect of Down-Wind Distance}

The calculated distribution of $\mathrm{CO}_{2}$ concentration is illustrated as profiles at several down-wind distances for the canopy 4 (Fig. 9). The profile is approximately logarithmic in the above-canopy space and exponential within the canopy. The concentration increased at every height as the fetch increased, and the relative increase was greater for increasing height. At the top of the crop canopy $(Z=1.0 \mathrm{~m})$, for example, the concentration above the ambient level increased from $10 \mathrm{ppm}$ at

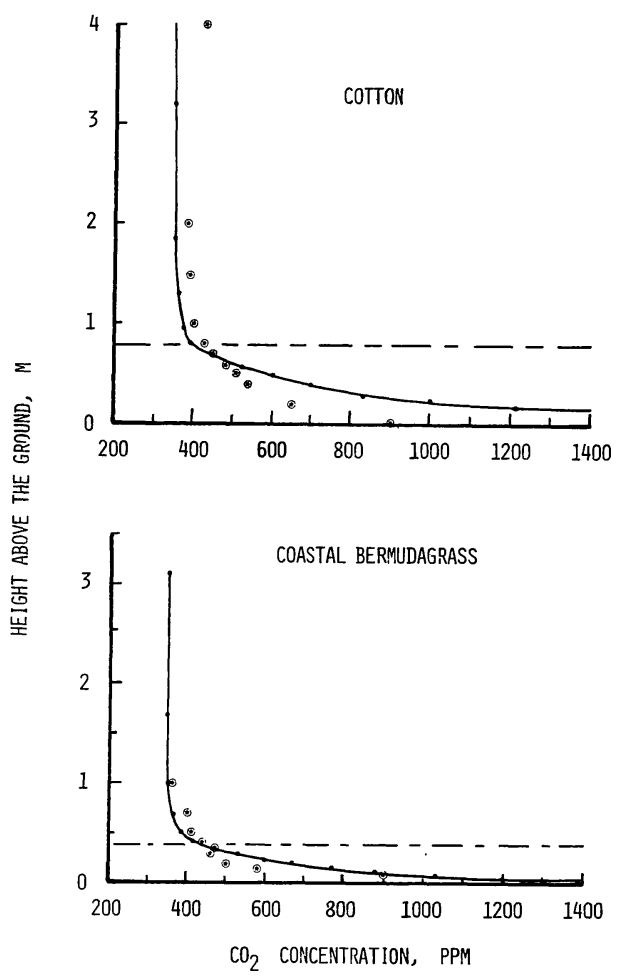

Fig. 8. Computed (solid line) and measured $\mathrm{CO}_{2}$ profiles in the experiments by Harper (1971), for a cotton (top) and a coastal bermudagrass (bottom) crop.

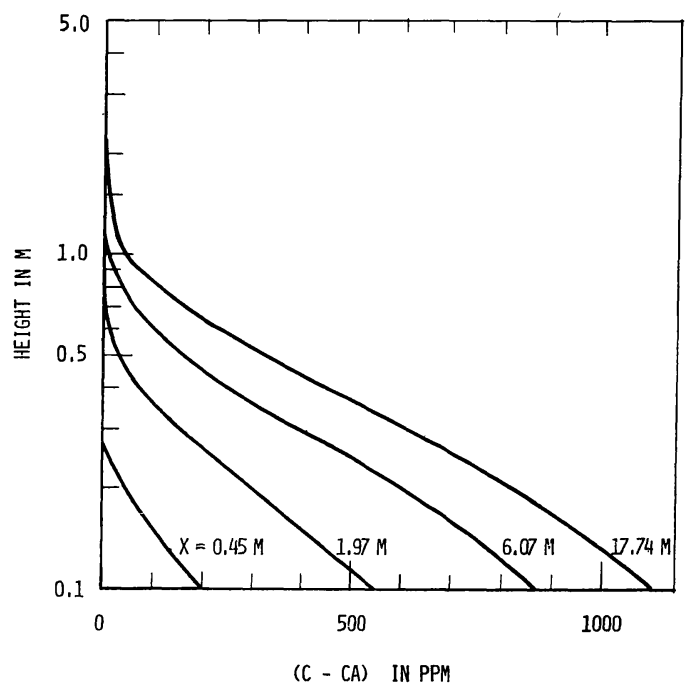

Fig. 9. $\mathrm{CO}_{2}$ profiles at four downwind distances $(X)$ for canopy 4 at $\bar{U}=2 \mathrm{~m} \mathrm{~s}^{-1}$ and $F S$ $=0.01 \mathrm{~g} \mathrm{~m}^{-2} \mathrm{~s}^{-1}$. 
$X=6 \mathrm{~m}$ to $40 \mathrm{ppm}$ at $X=18 \mathrm{~m}$, while it increased from $170 \mathrm{ppm}$ to $450 \mathrm{ppm}$ half way down in the canopy $(Z=0.5 \mathrm{~m})$ at the same two downwind distances from the leading edge.

The $\mathrm{CO}_{2}$ boundary layer thickness $(\mathrm{ZH}, \mathrm{m})$, the height at which $C$ converges to $C A$, can be expressed (Fig. 10) by

$$
Z H=b X^{a}
$$

There are three distinct regions: within the canopy, above the canopy and the transient region around the crop height, reflecting the different turbulent structure in each layer as expressed in the wind and eddy diffusivity profiles.

The value of parameter $a$ for within the canopy was between 1.00 and 1.55 , while it ranged from 0.60 to 0.73 for above the canopy. This implies that the $\mathrm{CO}_{2}$ boundary layer develops more rapidly inside the canopy, due to the intense vertical mixing. The constant $a$ appeared to be affected slightly by $D, Z 0, A$ and $U A$ or $F S$ above the canopy, while it was only affected by $D$ and $Z 0$ within the canopy. The value obtained for above the canopy is close to that reported by Inoue (1974), i.e., 0.7 to 0.8 .

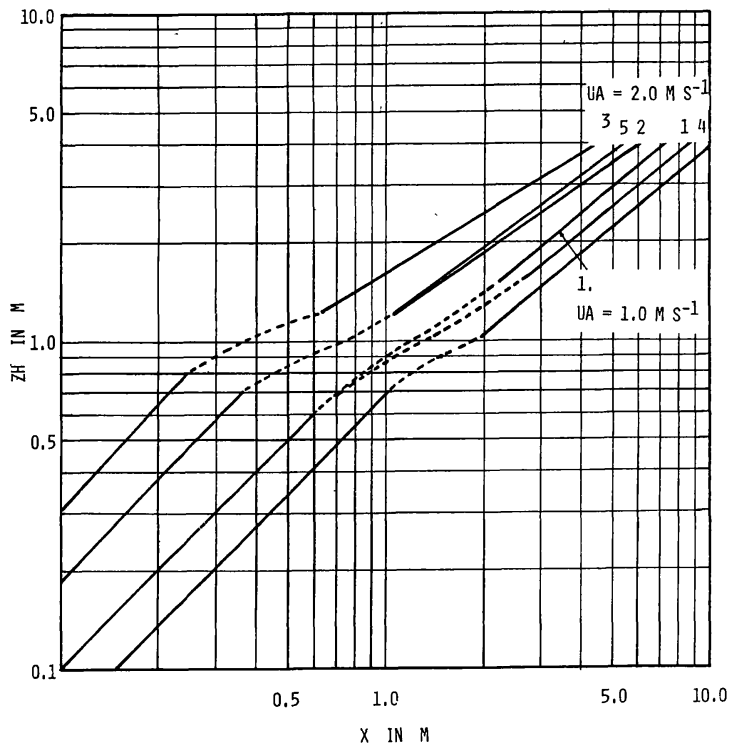

Fig. 10. Change of $\mathrm{CO}_{2}$ boundary layer thickness $(\mathrm{ZH})$ with downwind distance $(X)$ for five different crop canopies (1 through 5, see Table 1).

\section{Effect of Wind Speed and Release Rate}

Fig. 11 shows profiles at three wind speed levels and two release rates, for the canopy 1 , at $6.04 \mathrm{~m}$ downwind distance. The concentration at each height $(C(X, Z))$ is proportional to the release rate $(F S)$, and inversely proportional to the wind speed at $2 \mathrm{~m}$ height $(U A)$. The combined effect of $U A$ and $F S$ can be expressed as

$$
C(X, Z) \sim F S / U A
$$

This result is important because it can be used to generalize the simulation results by means of a scaling factor. For example, the $\mathrm{CO}_{2}$ concentration above ambient level would be 400 ppm half-way down inside the canopy, if the wind speed $(U A)$ was $0.5 \mathrm{~m} \mathrm{~s}^{-1}$ with a release rate of $0.01 \mathrm{~g} \mathrm{~m}^{-2} \mathrm{~s}^{-1}$, or if the release rate was $0.02 \mathrm{~g} \mathrm{~m}^{-2} \mathrm{~s}^{-1}$ at $1 \mathrm{~m} \mathrm{~s}^{-1}$ of wind speed. An increase of $400 \mathrm{ppm}$ could have a significant effect on the crop canopy behavior, as the maximum leaf density is usually found around the middle of the canopy.

\section{Effect of Aerodynamic Canopy Parameters}

Fig. 12 gives five profiles for the aerodynamically different types of canopies specified in Table 1 .

As $Z 0$ increased ((1) to (2), (4) to (3)), the profile

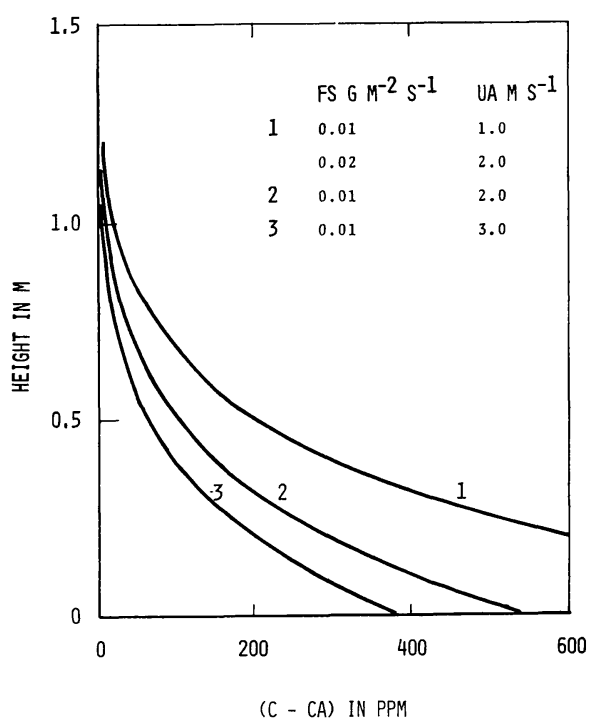

Fig. 11. $\mathrm{CO}_{2}$ profiles at the downwind distance of $6.04 \mathrm{~m}$ at different wind speeds and release rates for canopy 1 . 




Fig. 12. $\mathrm{CO}_{2}$ profiles for five different crop canopies (1 through 5, see Table 1) at the downwind distance of $6.04 \mathrm{~m}$ at a wind speed of $2 \mathrm{~m} \mathrm{~s}^{-1}$ and with a release rate of $0.01 \mathrm{~g} \mathrm{~m}^{-2} \mathrm{~s}^{-1}$.

became steeper. This is because the rougher surface enhanced the vertical eddy diffusion, while depressing horizontal advection by decreasing wind speed at the top of the canopy.

On the other hand, the concentration at each height increased, as $D$ increased ((1) to (4), (2) to (3)), the profile retaining the same shape. The effect is quite similar to that of $U A$ (Fig. 11). This is the result of loglaw and exponential wind profiles in which the eddy size or scale of turbulence inside the canopy is assumed (Inoue, 1963) to be proportional to $(H-D)$ and $U A$. In a dense canopy, characterized by a small $(H-D)$, the scale of turbulence is small, making the vertical eddy diffusion also small.

Comparison of profile (5) with (2) shows the effect of $A$. The concentration at each height decreased as $A$ increased. This suggests that, within the canopy, the vertical eddy mixing is more predominant than advective transport, since the decline of both eddy diffusivity and wind speed is the same as $A$ increased. The same conclusion has been reached by others, experimentally (Harper, et al., 1973) and theoretically (Inoue, 1963). The overall effect of $A$ is small compared with that of $D$ and $Z 0$. This is again the result of basic assumptions used to derive the exponential wind profile, i.e., the scale of turbulence is primarily determined in the surface boundary layer and is constant with height inside the canopy, being independent of leaf area density in commonly studied crop canopies (Kondo, 1972).

\section{Conclusion}

The numerical model presented here permits us to compute the two-dimensional distribution of $\mathrm{CO}_{2}$ for a given crop canopy, characterized by its aerodynamic properties, given the wind speed, the release rate, and the $\mathrm{CO}_{2}$ concentration in the non-release area. The experimental tests indicate that the model yields a good approximation for a dense and homogeneous canopy, at a steady state and in thermally neutral conditions. For non-homogeneous, "bunched" canopies the model overestimates the enrichment effect.

The $\mathrm{CO}_{2}$ concentration at a given point increases proportionally with the release rate, and inversely with the wind speed. Among the aerodynamic properties of the canopy, three parameters (crop canopy height, zeroplane displacement and roughness length) are important. The exponential coefficient of the within-canopy profile of the wind speed is less critical.

The model could be generalized by introducing the influence of atmospheric stability, although an adequate approach for this in the within-canopy space is yet to be found.

\section{Acknowledgements}

We express our thanks to C. D. Wakefield and A. McMillan for help in the field experiments, and K. J. McCree, K. W. Brown and K. Inoue for their valuable comments.

\section{List of Symbols}

$\begin{array}{clr}A & \begin{array}{l}\text { Exponential coefficient of within } \\ \text { canopy wind profile }\end{array} \\ C & \mathrm{CO}_{2} \text { concentration at a given point in } \\ & \text { space (also } C(I, J), C(V, W) \text { ) } & \mathrm{g} \mathrm{m}^{-3} \\ C A & \mathrm{CO}_{2} \text { concentration at the upwind } \\ & \text { edge (also } C(1, J) \text { ) } \\ D & \text { Zero-plane displacement } \\ \Delta V & \text { Grid spacing in the } V \text { direction }\end{array}$




\begin{tabular}{|c|c|c|}
\hline$\Delta W$ & Grid spacing in the $W$ direction & - \\
\hline$F K$ & Dimensionless eddy diffusivity at $W$ & - \\
\hline$F S$ & $\mathrm{CO}_{2}$ release rate & $\mathrm{g} \mathrm{m}^{-2} \mathrm{~s}$ \\
\hline$F U$ & Dimensionless wind speed at $W$ & {[} \\
\hline$F 1$ & $\begin{array}{l}\text { Auxiliary variable for computation } \\
(=F S * H / K H)\end{array}$ & $\mathrm{g} \mathrm{m}^{-3}$ \\
\hline$G 1, G 2$ & $\begin{array}{l}\text { Dimensionless function } \\
\text { (see eq. (11)) }\end{array}$ & - \\
\hline$H$ & Crop canopy height & $\mathrm{m}$ \\
\hline$I$ & $\begin{array}{l}\text { Index of grid point in the } V \\
\text { direction }\end{array}$ & - \\
\hline$J$ & $\begin{array}{l}\text { Index of grid point in the } W \\
\text { direction }\end{array}$ & - \\
\hline$K$ & Eddy diffusivity at $Z$ & $\mathrm{~m}^{2} \mathrm{~s}^{-1}$ \\
\hline$k$ & Von Karman constant $(=0.4)$ & - \\
\hline$K H$ & Eddy diffusivity at $H$ & $\mathrm{~m}^{2} \mathrm{~s}^{-1}$ \\
\hline$L A D$ & Leaf area density & $\mathrm{m}^{2} \mathrm{~m}^{-3}$ \\
\hline$L A I$ & Leaf area index & $\mathrm{m}^{2} \mathrm{~m}^{-2}$ \\
\hline$R 1$ & $\begin{array}{l}\text { Auxiliary variable for computation } \\
(=\Delta V / \Delta W)\end{array}$ & \\
\hline$R 2$ & $\begin{array}{l}\text { Auxiliary variable for computation } \\
\left(=\Delta V /(\Delta W)^{2}\right)\end{array}$ & - \\
\hline$U$ & Wind speed at $Z$ & $\mathrm{~m} \mathrm{~s}^{-1}$ \\
\hline$U A$ & Wind speed at $Z A$ & $\mathrm{~m} \mathrm{~s}^{-1}$ \\
\hline$U H$ & Wind speed at $H$ & $\mathrm{~m} \mathrm{~s}^{-1}$ \\
\hline$V$ & Dimensionless downwind distance & - \\
\hline$W$ & Dimensionless height & \\
\hline$W D$ & $\begin{array}{l}\text { Dimensionless zero-plane } \\
\text { displacement }(=D / H)\end{array}$ & \\
\hline$W H$ & $\begin{array}{l}\text { Dimensionless height of internal } \\
\mathrm{CO}_{2} \text { boundary layer }(=\mathrm{ZH} / \mathrm{H})\end{array}$ & 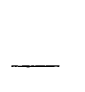 \\
\hline$W Z 0$ & $\begin{array}{l}\text { Dimensionless roughness length } \\
(=Z 0 / H)\end{array}$ & \\
\hline$X$ & $\begin{array}{l}\text { Abscissa measured downwind from } \\
\text { the leading edge of the } \mathrm{CO}_{2} \text { release } \\
\text { area }\end{array}$ & $\mathrm{m}$ \\
\hline$Z$ & $\begin{array}{l}\text { Ordinate measured upward from } \\
\text { the ground surface }\end{array}$ & $\mathrm{m}$ \\
\hline$Z A$ & $\begin{array}{l}\text { Height in the crop surface bound- } \\
\text { ary layer }\end{array}$ & $\mathrm{m}$ \\
\hline$Z H$ & $\begin{array}{l}\text { Height of the internal } \mathrm{CO}_{2} \text { bound- } \\
\text { ary layer }\end{array}$ & $\mathrm{m}$ \\
\hline$Z 0$ & Roughness length & $\mathrm{m}$ \\
\hline
\end{tabular}

\section{Literature Cited}

Allen, L.H., Jr. 1973. Crop micrometeorology: A. Widerow light penetration. B. Carbon dioxide enrichment and diffusion. Ph.D. Dissertation, Cornell University, Ithaca, New York. 366p.

Allen, L.H., Jr. 1974. Line source carbon dioxide release. II. Two-dimensional numerical diffusion model. Agron. J. 66:616-620.

Allen, L.H., Jr., R.L. Desjardins, and E.R. Lemon. 1974. Line source carbon dioxide release. I. Field experiment. Agron. J. 66:609-615.

Allen, L.H., Jr., S.E. Jensen, and E.R. Lemon. 1971. Plant response ${ }_{\star}$ to carbon dioxide enrichment under field conditions: simulation. Science 173:256-258.

Brown, K.W., and N.J. Rosenberg. 1970. Concentration of $\mathrm{CO}_{2}$ in the air above a sugar beet field. Monthly Weather Review 98:75-82.

Budyko, M.T., L.S. Gandin, and N.A. Efimova. 1966. Application of physical method to the study of agricultural index. Meteorology and Hydrology 5:3-10. (Japanese Transl. from Russian. In Biological Science 19:56-59).

Duncan, W.G., and B.J. Barfield. 1970. Predicting effects of $\mathrm{CO}_{2}$ enrichment with sim lation models and a digital computer. ASAE, Trans. 13:246-248.

Gaastra, P. 1954. Photosynthesis of crop plants as influenced by light, carbon dioxide, temperature and stomatal diffusion resistance. Meded. Landbouwhogeschool. Wageningen 59:1-68.

Harper, L.A. 1971. Mass and energy transfer between the atmosphere and two plant canopy types. Ph.D. Thesis, University of Georgia, Athens, Georgia. 122p.

Harper, L.A., D.N. Baker, J.E. Box, Jr., and J.D. Hesketh. 1973. Carbon dioxide and the photosynthesis of field crops: A metered carbon dioxide release in cotton under field conditions. Agron. J. 65:7-11.

Inoue, E. 1963. On the turbulent structure of air-flow within crop canopies. J. Met. Soc. Japan 41:317-326.

Inoue, K. 1974. Numerical experiments of effects of advection of $\mathrm{CO}_{2}$ environment and photosynthesis of crop fields. Bull. Natl. Inst. Agric. Sci. Ser. A. 21:125. Tokyo, Japan.

Kondo, J. 1972. On a product of mixing length and coefficient of momentum absorption within plant canopies. J. Meteor. Soc. Japan 50:487-488.

Kretchman, D.W., and F.S. Howlett. 1970. $\mathrm{CO}_{2}$ enrichment for vegetable production. ASAE, Trans. 13: 252-256.

Lemon, E.R., D.W. Stewart, and R.W. Shawcroft. 1971. The sun's work in a cornfield. Science 174:371-378.

Monteith, J. L. 1973. Principles of environmental 
physics. American Elsevier Publishing Company, Inc., New York. 241p.

Stanhill, G. and M. Fuchs. 1968. The climate of the cotton crop: Physical characteristics and microclimate relationships. Agr. Meteorol. 5:183-202.

Sutton, O.G. 1953. Micrometeorology. McGraw-Hill, New York. 333p.

Takami, S. 1974. The distribution of carbon dioxide released from a ground level area source in a field crop and its predicted influence on crop assimilation. Ph.D. Dissertation, Texas A\&M University, College Station, Texas. 129p.

Takeda, K. 1966. On roughness length and zero-plane displacement in the wind profile of the lowest air layer. J. Meteor. Soc. Japan 30:101-107.
Uchijima, Z. and K. Inoue. 1970. Studies of energy and gas exchange within crop canopies (9): Simulation of $\mathrm{CO}_{2}$ environment within a canopy. J. Agr. Meteorol. Tokyo 26:5-18.

Uchijima, Z., T. Udagawa, T. Horie, and K. Kobayashi. 1967. Studies of energy and gas exchange within crop canopies (1): $\mathrm{CO}_{2}$ environment in a corn plant canopy. J. Agr. Meteorol. Tokyo 23:99-108.

Van Bavel, C.H.M. 1972. Water use efficiency in plant growth and ambient carbon dioxide level. In: Technical Report 42. Texas Water Resources Institute, Texas A\&M University, 1-38.

\title{
野外群落内で放出された炭酸ガスの分布
}

\author{
高見晋一・・シー・エイチ・エム・ファンバベル \\ (テキサス農工大，テキサス，米国）
}

要 約

植物群落内の地表面源から放出された炭酸ガスの定常二次元拡散をとりあつかうモデルを提出した。水平方向に均 一で無限な群落と風下方向に半無限で均一な面源を仮定し，炭酸ガス放出率は一定とした。

モデルは群落上に発達した境界層内の風速, 面源の風上端での炭酸ガス濃度そして放出率が与えられると, 任意の

風下距離において, 空気力学的パラメーターで特徵づけられた群落内外の炭酸ガス濃度の垂直分布を計算する。

一連の野外拡散実験でモデルをテストした。その結果, 風速変動が小さく中立状態の時, モデルは一様で密な群落 に対しては炭酸ガス濃度分布のよい推定值を与えることがわかった。

\footnotetext{
* 現在：東京大学農学部
} 